\title{
Anaerobic ammonium oxidation in an estuarine sediment
}

\author{
Nils Risgaard-Petersen ${ }^{1, *}$, Rikke Louise Meyer ${ }^{2}$, Markus Schmid ${ }^{3}$, Mike S. M. Jetten ${ }^{4}$, \\ Alex Enrich-Prast ${ }^{5}$, Søren Rysgaard ${ }^{1}$, Niels Peter Revsbech ${ }^{2}$ \\ ${ }^{1}$ National Environmental Research Institute, Department of Marine Ecology, Vejlsøvej 25, 8600 Silkeborg, Denmark \\ ${ }^{2}$ University of Aarhus, Institute of Biological Sciences, Department of Microbial Ecology, Ny Munkegade Building 540, \\ 8000 Århus $\mathrm{C}$, Denmark \\ ${ }^{3}$ Delft University of Technology, Department of Biotechnology, Delft, The Netherlands \\ ${ }^{4}$ KU Nijmegen, Department of Microbiology, Nijmegen, The Netherlands \\ ${ }^{5}$ Depto. Ecologia, CCS, Ilha do Fundao, Cidade Universitaria, Universidade Federal do Rio de Janeiro, Rio de Janeiro, \\ 21951-590, Brasil
}

\begin{abstract}
The occurrence and significance of the anammox (anaerobic ammonium oxidation) process

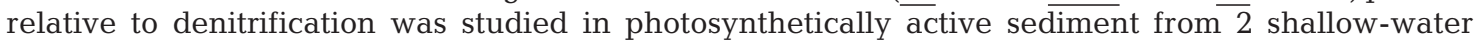
estuaries: Randers Fjord and Norsminde Fjord, Denmark. Anammox accounted for 5 to $24 \%$ of $\mathrm{N}_{2}$ production in Randers Fjord sediment, whereas no indication was seen of the process in sediment from Norsminde Fjord. It is suggested that the presence of anammox in Randers Fjord and its absence from Norsminde Fjord is associated with differences in the availability of $\mathrm{NO}_{3}{ }^{-}+\mathrm{NO}_{2}^{-}\left(\mathrm{NO}_{\mathrm{x}}{ }^{-}\right)$in the suboxic zone of the sediment. In Randers Fjord, $\mathrm{NO}_{\mathrm{x}}{ }^{-}$is present in the water column throughout the year and $\mathrm{NO}_{\mathrm{x}}{ }^{-}$ porewater profiles showed that $\mathrm{NO}_{\mathrm{x}}^{-}$penetrates into the suboxic zone of the sediment. In Norsminde Fjord, $\mathrm{NO}_{\mathrm{x}}{ }^{-}$is absent from the water column during the summer months and, via assimilation, benthic microalgae may prevent penetration of $\mathrm{NO}_{\mathrm{x}}{ }^{-}$into the suboxic zone of the sediment. Volume-specific anammox rates in Randers Fjord were comparable with rates measured previously in Skagerrak sediment by other investigators, but denitrification rates were 10 to 15 times higher. Thus, anammox contributes less to $\mathrm{N}_{2}$ production in Randers Fjord than in Skagerrak sediment. We propose that the lower contribution of anammox in Randers Fjord is linked to the higher availability of easily accessible carbon, which supports a higher population of denitrifying bacteria. Amplification of DNA extracted from the sediment samples from Randers Fjord using planctomycete-specific primers yielded 16S rRNA gene sequences closely related to candidatus Scalindua sorokinii found in the Black Sea by other investigators. The present study thus confirms the link between the presence of bacteria affiliated with candidatus S. sorokinii and the anammox reaction in marine environments. Anammox rates in sediment with intact chemical gradients were estimated using both ${ }^{15} \mathrm{~N}$ and microsensor techniques. Anammox rates estimated with microsensors were less than $22 \%$ of the rates measured with isotopes. It is suggested that this discrepancy was due to the presence of fauna, because the applied ${ }^{15} \mathrm{~N}$ technique captures total $\mathrm{N}_{2}$ production while the microsensor technique only captures diffusion-controlled $\mathrm{N}_{2}$ production at the sediment surface. This hypothesis was verified by consistent agreement between the methods when applied to defaunated sediments.
\end{abstract}

KEY WORDS: Anammox · Denitrification $\cdot$ Planctomycetes $\cdot$ Scalindula

\section{INTRODUCTION}

The biologically mediated reduction of $\mathrm{NO}_{3}{ }^{-}+$ $\mathrm{NO}_{2}^{-}\left(\mathrm{NO}_{\mathrm{x}}^{-}\right)$to $\mathrm{N}_{2}$ through denitrification is generally considered to be the major process responsible for removal of nitrogen from the sea (Devol 1991). Until recently, it was believed that denitrification was based solely on the reduction of $\mathrm{NO}_{\mathrm{x}}{ }^{-}$to $\mathrm{N}_{2}$ in an oxygen-free environment by facultatively aerobic bacteria with an organotrophic metabolism (Zumft 1992). Within this 
model, the major $\mathrm{NO}_{\mathrm{x}}{ }^{-}$source for denitrification is nitrification, i.e. the bacterial oxidation of $\mathrm{NH}_{4}{ }^{+}$or $\mathrm{NO}_{2}{ }^{-}$ with $\mathrm{O}_{2}$. Nitrification and denitrification are associated with the sediment/water interface in marine sediments. Nitrification takes place in the upper oxic zone of the sediment and denitrification in the suboxic zone just below the oxic/suboxic interface (Jensen et al. 1993, 1994). According to the classical concept, coupled nitrification-denitrification is facilitated by the transport of $\mathrm{NO}_{\mathrm{x}}^{-}$from the oxic $\mathrm{NO}_{\mathrm{x}}{ }^{-}$production zones to the suboxic $\mathrm{NO}_{\mathrm{x}}^{-}$consumption zones in the sediment. In bioturbated sediments, the transport of $\mathrm{NO}_{\mathrm{x}}^{-}$ from oxic to suboxic zones may be further enhanced by fauna-mediated processes such as biodiffusion and irrigation (Aller 1982, Aller \& Aller 1998, Kristensen 2000 and references therein). This enhanced transport results in elevated production of $\mathrm{N}_{2}$ (e.g. Pelegri et al. 1994, Svensson et al. 2001, Newell et al. 2002).

The classical view has recently been challenged by the discovery of alternative pathways of combined nitrogen transformations. These alternative pathways include the anaerobic oxidation of $\mathrm{NH}_{4}{ }^{+}$to $\mathrm{NO}_{3}{ }^{-}$or $\mathrm{N}_{2}$ with manganese oxides (Luther et al. 1997, Hulth et al. 1999) and the anaerobic oxidation of $\mathrm{NH}_{4}{ }^{+}$to $\mathrm{N}_{2}$ with $\mathrm{NO}_{2}^{-}$(Mulder et al. 1995). While direct experimental evidence for anaerobic $\mathrm{NH}_{4}{ }^{+}$oxidation to $\mathrm{N}_{2}$ with manganese oxides is still lacking (Thamdrup \& Dalsgaard 2000), it is now well documented that $\mathrm{NH}_{4}{ }^{+}$can be oxidized anaerobically to $\mathrm{N}_{2}$ with $\mathrm{NO}_{2}{ }^{-}$both in marine sediments and in open waters (Dalsgaard \& Thamdrup 2002, Thamdrup \& Dalsgaard 2002, Dalsgaard et al. 2003, Kuypers et al. 2003, Trimmer et al. 2003). This biologically mediated process is called anammox (anaerobic ammonium oxidation) (Strous et al. 1999). Strictly viewed, anammox is equivalent to denitrification since denitrification is defined as the conversion of $\mathrm{NO}_{2}{ }^{-}$to gaseous $\mathrm{N}$ (Payne 1981). However, existing literature addressing anammox in natural environments (Dalsgaard \& Thamdrup 2002, Thamdrup \& Dalsgaard 2002, Trimmer et al. 2003) uses the term denitrification for the purely $\mathrm{NO}_{\mathrm{x}}^{-}$-based $\mathrm{N}_{2}$ production (E-donor $+2 \mathrm{NO}_{\mathrm{x}}{ }^{-} \rightarrow \mathrm{N}_{2}$ ) and the term anammox for the production of $\mathrm{N}_{2}$ from $\mathrm{NH}_{4}{ }^{+}$and $\mathrm{NO}_{2}{ }^{-}$. For the sake of consistency, we choose to follow this nomenclature.

Little is known about the biogeography of the anammox process, its microbiology, and its importance as a source of $\mathrm{N}_{2}$ production relative to denitrification. According to current knowledge, the anammox process is carried out by autotrophic, obligately anaerobic bacteria of the phylum Planctomycetes (Strous et al. 1999, Schmid et al. 2000, 2003, Kuypers et al. 2003). Knowledge of the microbiology of the process in marine environments is limited to a single study in the Black Sea (Kuypers et al. 2003), which, however, also linked the occurrence of the anammox process to the occurrence of anammox bacteria of the phylum Planctomycetes. The few published data addressing the occurrence and significance of this newly discovered process in marine environments originate mainly from studies of deep-water, offshore sediments and anoxic water columns (see Dalsgaard \& Thamdrup 2002, Thamdrup \& Dalsgaard 2002, Dalsgaard et al. 2003, Kuypers et al. 2003). These studies suggested that the anammox reaction may account for 30 to $70 \%$ of oceanic $\mathrm{N}_{2}$ production (Devol 2003), which poses a great challenge to our view on the control of marine $\mathrm{N}_{2}$ production. Only very recently has anammox activity been located in estuarine sediment from the Thames estuary, UK (Trimmer et al. 2003), where it accounted for $<10 \%$ of benthic $\mathrm{N}_{2}$ production.

The present study addresses the occurrence and significance of the anammox process relative to denitrification in photosynthetically active sediments from 2 shallow-water estuaries: Randers Fjord and Norsminde Fjord, Denmark. We identified bacteria responsible for the process using anammox-specific FISH (fluorescence in situ hybridization) probes, 16S rRNA genetargeted PCR amplification with anammox-specific primers, and subsequent sequencing and phylogenetic analysis (Schmid et al. 2000). We furthermore obtained quantitative data on the denitrification and anammox process rates. In order to compare the results of the present study with data from previous studies of the anammox process in marine sediments, we assessed anammox and denitrification activity in sediment slurries according to Thamdrup \& Dalsgaard (2002). This technique estimates the volume-specific anammox and denitrification rates. To assess process rates in sediments with intact chemical gradients, we combined techniques that estimate benthic $\mathrm{N}_{2}$ production in intact sediment cores (Nielsen 1992, Risgaard-Petersen et al. 2003) with the ${ }^{15} \mathrm{~N}$ technique of Thamdrup \& Dalsgaard (2002), which also estimates the contribution of anammox to total $\mathrm{N}_{2}$ production. In addition, $\mathrm{N}_{2}$ production was estimated from porewater profiles of $\mathrm{NO}_{\mathrm{x}}^{-}$, to address the diffusion-controlled activity directly linked to the sediment surface. Microsensor profiles of $\mathrm{O}_{2}$ and $\mathrm{NO}_{\mathrm{x}}{ }^{-}$were furthermore used to obtain a detailed picture of the distribution of oxic and suboxic zones as well as zones of $\mathrm{NO}_{\mathrm{x}}^{-}$production and consumption. As $\mathrm{O}_{2}$ exposure and $\mathrm{NO}_{\mathrm{x}}^{-}$availability would be key factors in determining the distribution of anammox bacteria in the sediment, these detailed observations could explain some of the trends observed in anammox activity.

The first phase of this study took place in June 2001. During this phase we quantified anammox and denitrification rates in intact cores and in prepared cores from which fauna had been removed. The second phase took place in April, June and September 2003. In this 
phase we revisited the sites to further validate the existence of the anammox process, and we furthermore analyzed occurrence of anammox bacteria using the molecular techniques described above.

\section{MATERIALS AND METHODS}

Study sites. The study was carried out in Randers Fjord and Norsminde Fjord, Denmark. Randers Fjord is a shallow eutrophic estuary, $27 \mathrm{~km}$ long. The study site, Mellerup, is situated $12 \mathrm{~km}$ from the mouth of the estuary and at this site salinity ranges from 3 to $15 \mathrm{psu}$. Water-column concentrations of $\mathrm{NO}_{3}^{-}+\mathrm{NO}_{2}^{-}\left(\mathrm{NO}_{\mathrm{x}}^{-}\right)$ range from 15 to $300 \mu \mathrm{M}$ over the year and $\mathrm{N}_{2}$ production from 2 to $6 \mathrm{mmol} \mathrm{m}^{-2} \mathrm{~d}^{-1}$ (County of Aarhus 1999). The average water depth at the station is approximately $1 \mathrm{~m}$. The sediment consists of very fine sand with a moderate content of organic C ( $4 \%$ ignition loss) (see Table 1). Benthic microalgae (mainly diatoms) were present at the sediment surface. Norsminde Fjord is a shallow eutrophic estuary, $5 \mathrm{~km}$ long. The study site Kysing is situated near the outlet, and at this site salinity ranges from 3 to 23.5 psu while $\mathrm{NO}_{\mathrm{x}}{ }^{-}$Concentrations range from $430 \mu \mathrm{M}$ to below detection limit over the year, the minimum being found in the summer months (County of Aarhus 1994). $\mathrm{N}_{2}$ production ranges from 0.2 to $1.6 \mathrm{mmol} \mathrm{m}^{-2} \mathrm{~d}^{-1}$ (Nielsen et al. 1995). The average water depth at the station is approximately $0.5 \mathrm{~m}$. The sediment consists of medium sand with a moderate content of organic C (4\% ignition loss; see Table 1). Benthic microalgae (mainly diatoms) are present and periodically form dense mats.

Sediment sampling and handling. Sediment was sampled by hand in Plexiglas tubes at both of the sites. Cores for measurement of total $\mathrm{N}_{2}$ production, $\mathrm{NO}_{\mathrm{x}}{ }^{-}$and $\mathrm{O}_{2}$ exchange rates anammox rates, and determination of sediment characteristics were collected in $300 \mathrm{~mm}$ tubes (inner diameter, i.d., $5.5 \mathrm{~mm}$ ). Cores used for microsensor measurements of $\mathrm{O}_{2}$ and $\mathrm{NO}_{\mathrm{x}}^{-}$porewater profiles were collected in $100 \mathrm{~mm}$ tubes (i.d. $55 \mathrm{~mm}$ ).

Another batch of surface sediment was collected in Randers Fjord, sieved through a $1 \mathrm{~mm}$ mesh screen, and transferred to a plastic container. Sediment cores were then sampled from the container by core tubes of the type used for in situ sampling.

All cores were processed on return to the laboratory. The lengths of the sediment cores used for measurement of total $\mathrm{N}_{2}$ production and exchange rates of dissolved inorganic nitrogen (DIN) and $\mathrm{O}_{2}$ were adjusted to $10 \mathrm{~cm}$, and magnetic stir bars were positioned about $5 \mathrm{~cm}$ above the sediment surface. The cores were then placed in a reservoir containing site water held at in situ temperature. An external magnetic rotor (ca. 50 rpm) ensured stirring of the water inside the tubes. Cores for microsensor measurements were pushed upward in the Plexiglas cylinder until the surface of the sediment was flush with the cylinder edge, and then placed in an aerated reservoir. Measurements of process rates were initiated within $12 \mathrm{~h}$. Cores containing sieved sediment were pre-incubated as described above in darkness for $1 \mathrm{wk}$ in aerated seawater held at $17^{\circ} \mathrm{C}$ to allow microbial processes in the sediment to stabilize.

Anammox and denitrification in slurry incubations. In the first phase of the study we used a simplified version of the technique devised by Thamdrup \& Dalsgaard (2002), which allowed us to address only the presence or absence of the anammox process and the contribution of anammox to benthic $\mathrm{N}_{2}$ production. Slurries were prepared by transferring approximately $1 \mathrm{ml}$ of homogenized sediment from the upper $0.5 \mathrm{~cm}$ of the intact Randers Fjord sediment, the sieved Randers Fjord sediment and the intact Norsminde Fjord sediment, to $12 \mathrm{ml}$ gas-tight (Laughlin \& Stevens 2003) glass vials (Exetainer, Labco). These vials were placed in an $\mathrm{N}_{2}$ atmosphere inside a glove bag. The headspace of each vial was then purged with $\mathrm{N}_{2}$ and capped. The samples were left to stand for $4 \mathrm{~h}$ to eliminate the background concentration of $\mathrm{NO}_{\mathrm{x}}{ }^{-}$in the sediments. Test experiments showed that $\mathrm{NO}_{\mathrm{x}}{ }^{-}$was absent after $2 \mathrm{~h}$ pre-incubation. $\mathrm{N}_{2}$-purged artificial seawater (Grasshoff et al. 1983) containing either $100 \mu \mathrm{M}^{15} \mathrm{NO}_{3}{ }^{-}\left({ }^{15} \mathrm{~N}\right.$ at. \%: 97.5), $100 \mu \mathrm{M}^{15} \mathrm{NH}_{4}{ }^{+}\left({ }^{15} \mathrm{~N}\right.$ at. \%: 99) or $100 \mu \mathrm{M}^{15} \mathrm{NH}_{4}{ }^{+}$plus $100 \mu \mathrm{M}^{14} \mathrm{NO}_{3}^{-}$was then added to the vials ( $\mathrm{n}=4$ for each combination). The vials were transferred to a gas-tight bag purged with $\mathrm{N}_{2}$ and placed on a shaker tray. After $24 \mathrm{~h}, 200 \mu \mathrm{l}$ of a $7 \mathrm{M} \mathrm{ZnCl}_{2}$ solution were added to the slurries to stop bacterial activity.

In the second phase of the study, we used a slurry technique that allowed us to quantify volume-specific anammox and denitrification rates. The slurries were prepared as described above with the following modifications: Sediment of known weight and density was transferred to the glass vials together with $\mathrm{N}_{2}$-purged site water. The slurries were then pre-incubated for $18 \mathrm{~h}$ to remove $\mathrm{NO}_{\mathrm{x}}^{-}$in sediment and incubation media through denitrification and anammox. Control measurements of $\mathrm{O}_{2}$ and $\mathrm{NO}_{\mathrm{x}}{ }^{-}$confirmed that both $\mathrm{O}_{2}$ and $\mathrm{NO}_{\mathrm{x}}{ }^{-}$were depleted after this period. Subsequently, $100 \mu \mathrm{l}$ of $\mathrm{N}_{2}$-purged stock solution of each isotopic mixture, i.e. (1) ${ }^{15} \mathrm{NO}_{3}{ }^{-}\left({ }^{15} \mathrm{~N}\right.$ at.\%: 99), (2) ${ }^{15} \mathrm{NH}_{4}{ }^{+}\left({ }^{15} \mathrm{~N}\right.$ at. \%: 99.6) and (3) ${ }^{15} \mathrm{NH}_{4}{ }^{+}+{ }^{14} \mathrm{NO}_{3}$ was added with a Hamilton syringe resulting in a concentration of about $100 \mu \mathrm{m} \mathrm{N}\left(200 \mu \mathrm{m} \mathrm{N}\right.$ in the ${ }^{15} \mathrm{NH}_{4}{ }^{+}$ and ${ }^{14} \mathrm{NO}_{3}{ }^{-}$combination). Slurries based on ${ }^{15} \mathrm{NO}_{2}{ }^{-}$ additions were prepared in a similar manner. Incubations of the slurries were stopped at $1 \mathrm{~h}$ intervals by adding $200 \mu$ of a $7 \mathrm{M} \mathrm{ZnCl}_{2}$ solution. The abundance 
of ${ }^{15} \mathrm{~N}_{2}$-labeled gas $\left({ }^{29} \mathrm{~N}_{2}\right.$ and $\left.{ }^{30} \mathrm{~N}_{2}\right)$ in the samples was measured by combined gas chromatography/mass spectrometry (RoboPrep-G+ in line with Tracermass, Europa Scientific) as described by Risgaard-Petersen \& Rysgaard (1995).

Production of ${ }^{15} \mathrm{~N}_{2}$ gas in ${ }^{15} \mathrm{NH}_{4}{ }^{+}+{ }^{14} \mathrm{NO}_{3}{ }^{-}$-amended samples and absence of ${ }^{15} \mathrm{~N}_{2}$ production from samples incubated only with ${ }^{15} \mathrm{NH}_{4}{ }^{+}$was interpreted as evidence of anammox activity (Thamdrup \& Dalsgaard 2002). Anammox, denitrification and the contribution of anammox to $\mathrm{N}_{2}$ production were calculated from the production of ${ }^{29} \mathrm{~N}_{2}$ and ${ }^{30} \mathrm{~N}_{2}$ in the samples amended with ${ }^{15} \mathrm{NO}_{3}{ }^{-}$or ${ }^{15} \mathrm{NO}_{2}{ }^{-}$using the expressions of Thamdrup \& Dalsgaard (2002).

Total $\mathbf{N}_{2}$ production rates and nutrient fluxes. For both the Randers Fjord and the Norsminde Fjord sediment, total $\mathrm{N}_{2}$ production rates and $\mathrm{O}_{2}$ and $\mathrm{NO}_{\mathrm{x}}^{-}$ exchange rates were estimated in light and in darkness ( $\mathrm{n}=5$ for each treatment). Light was provided by $400 \mathrm{~W}$ greenhouse lamps (HPI-T+ mercury, Philips). Irradiance at the sediment surface (photon flux density) was $200 \mu \mathrm{mol} \mathrm{m}{ }^{-2} \mathrm{~s}^{-1}$. Process rates in the sieved Randers Fjord sediment were only determined in the dark $(\mathrm{n}=5) . \mathrm{N}_{2}$ production was measured with ${ }^{15} \mathrm{NO}_{3}{ }^{-}$ as described by Risgaard-Petersen \& Rysgaard (1995) and Dalsgaard et al. (2000). Exchange rates of $\mathrm{O}_{2}$ and $\mathrm{NO}_{\mathrm{x}}{ }^{-}$were likewise measured as described by Dalsgaard et al. (2000). Incubations were performed in 2 sessions: fluxes were measured first, and after an equilibrium period of $20 \mathrm{~h}$ the $\mathrm{N}_{2}$ production measurements were performed. All measurements were initiated $4 \mathrm{~h}$ after a change in light regime. Abundance of ${ }^{15} \mathrm{~N}_{2}\left({ }^{29} \mathrm{~N}_{2}\right.$ and $\left.{ }^{30} \mathrm{~N}_{2}\right)$ gas in the ${ }^{15} \mathrm{NO}_{3}{ }^{-}$-amended cores was measured by combined gas chromatography/mass spectrometry as described above. Concentrations of $\mathrm{NO}_{3}{ }^{-}$and $\mathrm{NO}_{2}{ }^{-}$were determined by the vanadium chloride reduction method (Braman \& Hendrix 1989) on an $\mathrm{NO}_{\mathrm{x}}{ }^{-}$analyzer (Model 42c, Thermo Environmental Instruments). $\mathrm{O}_{2}$ was measured by Winkler titration (Grasshoff et al. 1983).

Total ${ }^{14} \mathrm{~N}-\mathrm{N}_{2}$ production rates were calculated from the production rates of ${ }^{29} \mathrm{~N}_{2}$ and ${ }^{30} \mathrm{~N}_{2}$ in the ${ }^{15} \mathrm{NO}_{3}{ }^{-}$amended cores using the isotope pairing technique (IPT) (Nielsen 1992). This technique may, however, overestimate benthic ${ }^{14} \mathrm{~N}-\mathrm{N}_{2}$ production, as the presence of anammox results in violation of central assumptions on which the IPT is based, i.e. independence between added ${ }^{15} \mathrm{NO}_{3}{ }^{-}$and ${ }^{14} \mathrm{~N}-\mathrm{N}_{2}$ production and binomial distribution of produced ${ }^{28} \mathrm{~N}_{2},{ }^{29} \mathrm{~N}_{2}$ and ${ }^{30} \mathrm{~N}_{2}$ (RisgaardPetersen et al. 2003). Therefore, we also used the procedure proposed by Risgaard-Petersen et al. (2003) for estimation of $\mathrm{N}_{2}$ production in sediments where denitrification and anammox coexist. For a thorough discussion of the 2 calculation procedures see RisgaardPetersen et al. (2003).
$\mathrm{O}_{2}$ and $\mathrm{NO}_{\mathrm{x}}{ }^{-}$porewater profiles. Diffusion-controlled $\mathrm{N}_{2}$ production at the sediment surface and diffusive $\mathrm{O}_{2}$ and $\mathrm{NO}_{\mathrm{x}}{ }^{-}$uptake were estimated from porewater profiles of $\mathrm{O}_{2}$ and $\mathrm{NO}_{\mathrm{x}}{ }^{-}$in the Randers Fjord sediment, the Norsminde Fjord sediment and the sieved Randers Fjord sediment $(n=5)$. Profiles in sediment cores from Randers Fjord and Norsminde Fjord were measured in darkness and during illumination (irradiance: $200 \mu \mathrm{mol}$ photons $\mathrm{m}^{-2} \mathrm{~s}^{-1}$ ). Light was provided by a halogen lamp. Profile measurements in cores of sieved sediment were performed only in darkness. A Clark-type $\mathrm{O}_{2}$ sensor (Revsbech 1989), and a nitrate plus nitrite $\left(\mathrm{NO}_{\mathrm{x}}{ }^{-}\right)$biosensor (Larsen et al. 1997) were used to measure concentration profiles of $\mathrm{O}_{2}$ and $\mathrm{NO}_{\mathrm{x}}^{-}$, respectively. The measurements were performed as described by Meyer et al. (2001). Profiles of $\mathrm{O}_{2}$ and $\mathrm{NO}_{\mathrm{x}}^{-}$production rates were obtained by modeling the experimental data using the numerical method described by Berg et al. (1998). The sediment diffusion coefficient $\left(D_{s}\right)$ used in these calculations was estimated from the free-solution diffusion coefficient of $\mathrm{O}_{2}$ and $\mathrm{NO}_{3}{ }^{-}$(Li \& Gregory 1974) and sediment porosity (Boudreau 1997). Diffusive $\mathrm{O}_{2}$ and $\mathrm{NO}_{\mathrm{x}}{ }^{-}$uptake was calculated as the difference between the depthintegrated production and consumption estimated from the profiles of $\mathrm{O}_{2}$ and $\mathrm{NO}_{\mathrm{x}}^{-}$production. Diffusive $\mathrm{N}_{2}$ production was estimated from the depth-integrated $\mathrm{NO}_{\mathrm{x}}^{-}$consumption rates in the suboxic sediment strata according to the following rationale: $\mathrm{N}_{2}$ production $\left(\mathrm{p}_{14}\right)$ is the sum of anammox and denitrification, and while $2 \mathrm{~N}_{2}-\mathrm{N}$ atoms are produced for every $\mathrm{NO}_{2}{ }^{-}$being reduced through anammox, only 1 $\mathrm{N}_{2}-\mathrm{N}$ atom is produced for every $\mathrm{NO}_{\mathrm{x}}{ }^{-}$being reduced through denitrification. Thus:

$$
\begin{aligned}
& \mathrm{p}_{14}=2 \cdot \mathrm{NO}_{2}^{-}{ }_{\text {anammox }}+\mathrm{NO}_{\mathrm{x}}^{-} \text {denitrification }
\end{aligned}
$$

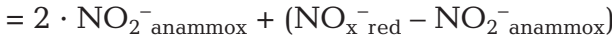

$$
\begin{aligned}
& =\mathrm{NO}_{2}{ }^{-} \text {anammox }+\mathrm{NO}_{\mathrm{x}}{ }^{-} \text {red }
\end{aligned}
$$

where $\mathrm{NO}_{2}{ }^{-}$anammox is the rate of $\mathrm{NO}_{2}{ }^{-}$reduction via the anammox process, $\mathrm{NO}_{\mathrm{x}}^{-}$denitrification is $\mathrm{NO}_{\mathrm{x}}{ }^{-}$reduction via denitrification and $\mathrm{NO}_{\mathrm{x}}^{-}$red is the total rate of $\mathrm{NO}_{\mathrm{x}}{ }^{-} \mathrm{re}-$ duction in the $\mathrm{O}_{2}$-free sediment strata. The rate of $\mathrm{N}-\mathrm{N}_{2}$ production via anammox can be expressed as follows:

$2 \cdot \mathrm{NO}_{2}^{-}$anammox $=r a \cdot \mathrm{p}_{14}=r a \cdot\left(\mathrm{NO}_{2}^{-}\right.$anammox $+\mathrm{NO}_{\mathrm{x}}^{-}$red $)$

where $r a$ is the contribution of anammox to $\mathrm{N}_{2}$ production.

The rate of $\mathrm{NO}_{2}^{-}$reduction via anammox can then be expressed as follows:

$$
\mathrm{NO}_{2}{ }^{-} \text {anammox }=\frac{r a \cdot \mathrm{NO}^{-}{ }^{-} \text {red }}{2-r a}
$$

and $\mathrm{p}_{14}$ is thus equivalent to:

$$
\mathrm{p}_{14}=\mathrm{NO}_{\mathrm{x}}{ }^{-} \text {red }-\frac{r a \cdot \mathrm{NO}_{\mathrm{x}}^{-} \text {red }}{2-r a}
$$


As in the total $\mathrm{N}_{2}$ production measurements, we used the contribution of anammox to $\mathrm{N}_{2}$ production estimated through slurry incubations in the first phase of this study as a proxy for ra.

Phylogenetic inference and fluorescence in situ hybridization (FISH). Analyses for anammox bacteria were performed on sediment sampled from the upper $0.5 \mathrm{~cm}$ of the Randers Fjord sediment. DNA extraction, cloning, sequencing, phylogenetic inference and FISH experiments were performed as reported by Schmid et al. (2003). Probes used in this study were S- *-Amx-0368-a-A-18 (detecting all anammox organisms), S-*-BS-0820-a-A-22 (detecting candidatus Scalindua sorokinii and candidatus S. wagneri) and S-P-Planc-0046-a-A-18 (detecting bacteria in the phylum Planctomycetes). (For further probe details see www.probeBase.net; Loy et al. 2003.)

Sediment characteristics. Grain size distribution was determined on 3 pooled sediment cores from the sites as described by Berg et al. (2001). Sediment permeability was estimated from the porosity and the mean diameter of sediment particles using the Carman-Kozeny equation (Boudreau 1997). Chlorophyll a was determined on sediment subsamples collected from the upper $0.5 \mathrm{~cm}$ of the sediment $(\mathrm{n}=3)$ using the method of Lorenzen (1967). Organic carbon content and porosity (vol/vol) were likewise determined on sediment subsamples from the upper $0.5 \mathrm{~cm}$ ( $\mathrm{n}=$ 3 ), and estimated from loss on ignition and the water contents of known volumes of sediment. The fauna density was determined in 3 cores from the site. The sediment in these cores was sieved through a $0.5 \mathrm{~mm}$ sieve and animals found were sorted into groups and counted.

\section{RESULTS}

\section{Sediment characteristics}

More than $75 \%$ of the sediment particles in Randers Fjord were $<125 \mu \mathrm{m}$, and according to the UddenWenworth scheme (Fütterer 2000), the sediment from Randers could thus be characterized as very fine sand (Table 1). The sediment from Norsminde was somewhat coarser, with $63 \%<500 \mu \mathrm{m}$, and could be classified as medium sand. Sediment permeability was $4 \times$ $10^{-15} \mathrm{~m}^{-2}$ and $3 \times 10^{-14} \mathrm{~m}^{-2}$ in the Randers Fjord and Norsminde Fjord sediment, respectively, and according to Glud et al. (1996) both sediments can be perceived as being impermeable. There was no major difference in chlorophyll a or organic $\mathrm{C}$ content between the Randers Fjord and Norsminde Fjord sediments. Intact sediment cores from both Randers Fjord and Norsminde Fjord were densely populated with polychaetes and Corophium sp. The density of Corophium sp. was $6734 \pm 2105$ and $3978 \pm 1654$ individuals $\mathrm{m}^{-2}$ and the density of polychaetes was $2525 \pm 281$ and $1473 \pm 210$ individuals $\mathrm{m}^{-2}$ in Randers Fjord and Norsminde Fjord, respectively.

\section{Anammox and denitrification assessed through slurry incubations}

In the case of slurries amended with ${ }^{15} \mathrm{NH}_{4}{ }^{+}$only, significant accumulation of ${ }^{15} \mathrm{~N}_{2}$-labeled gas was not seen in either the Randers Fjord or the Norsminde Fjord sediment (Table 2). When both ${ }^{15} \mathrm{NH}_{4}{ }^{+}$and ${ }^{14} \mathrm{NO}_{3}^{-}$ were present, ${ }^{29} \mathrm{~N}_{2}$ accumulated in both the intact and

Table 1. Sediment characteristics of study sites in 2 shallow-water estuaries in Denmark. Values are means $(\mathrm{SE}), \mathrm{n}=3 ; \mathrm{nm}$ : not measured; DW: dry weight

\begin{tabular}{|c|c|c|c|c|c|c|c|c|c|}
\hline \multirow[t]{2}{*}{ Site } & \multicolumn{6}{|c|}{ Grain size distribution (\%) } & \multirow{2}{*}{$\begin{array}{l}\text { Porosity } \\
\text { (vol/vol) }\end{array}$} & \multirow{2}{*}{$\begin{array}{l}\text { Organic C } \\
(\% \text { of DW) }\end{array}$} & \multirow{2}{*}{$\begin{array}{l}\mathrm{Chl} \mathrm{a} \\
\left(\mathrm{g} \mathrm{m}^{-2}\right)\end{array}$} \\
\hline & $<63 \mu \mathrm{m}$ & $>63 \mu \mathrm{m}$ & $>125 \mu \mathrm{m}$ & $>250 \mu \mathrm{m}$ & $>500 \mu \mathrm{m}$ & $>1000 \mu \mathrm{m}$ & & & \\
\hline Randers Fjord (intact) & 19.1 & 56.1 & 14.3 & 1.1 & 0.5 & 8.9 & 0.72 & $4.2(0.2)$ & $5.08(0.2)$ \\
\hline Randers Fjord (sieved) & 26.1 & 48.6 & 24.0 & 1.0 & 0.3 & 0.0 & 0.72 & $\mathrm{~nm}$ & $\mathrm{~nm}$ \\
\hline Norsminde Fjord & 5.3 & 13.4 & 21.5 & 35.1 & 12.5 & 12.2 & 0.65 & $4.4(0.03)$ & $4.2(0.1)$ \\
\hline
\end{tabular}

Table 2. Concentrations $(\mu \mathrm{M})$ of accumulated ${ }^{15} \mathrm{~N}_{2}$ in slurries treated with either ${ }^{15} \mathrm{NO}_{3}{ }^{-},{ }^{15} \mathrm{NH}_{4}{ }^{+}$or ${ }^{15} \mathrm{NH}_{4}{ }^{+}+{ }^{14} \mathrm{NO}_{3}{ }^{-}$. The contribution of anammox to total $\mathrm{N}_{2}$ production ( $\mathrm{ra}$ ) in the ${ }^{15} \mathrm{NO}_{3}{ }^{-}$-amended slurries is presented as \% $\mathrm{N}_{2}$ produced via anammox. Values are means (SE), $\mathrm{n}=4$. Data are from Phase 1 of study, June 2001

\begin{tabular}{|c|c|c|c|c|c|c|c|}
\hline \multirow[t]{2}{*}{ Site } & \multicolumn{2}{|c|}{${ }^{15} \mathrm{NO}_{3}^{-}$} & \multicolumn{2}{|c|}{${ }^{15} \mathrm{NH}_{4}{ }^{+}$} & \multicolumn{2}{|c|}{${ }^{15} \mathrm{NH}_{4}{ }^{+}+{ }^{14} \mathrm{NO}_{3}^{-}$} & \multirow{2}{*}{$\begin{array}{c}r a \\
(\%)\end{array}$} \\
\hline & ${ }^{29} \mathrm{~N}_{2}$ & ${ }^{30} \mathrm{~N}_{2}$ & ${ }^{29} \mathrm{~N}_{2}$ & ${ }^{30} \mathrm{~N}_{2}$ & ${ }^{29} \mathrm{~N}_{2}$ & ${ }^{30} \mathrm{~N}_{2}$ & \\
\hline Randers Fjord & $5.39(1.43)$ & $41.190(4.70)$ & $0.05(0.017)$ & $0.00(0.001)$ & $2.48(0.305)$ & $0.03(0.007)$ & $6.2(1)$ \\
\hline Randers Fjord (sieved) & $8.27(0.629)$ & $44.70(0.899)$ & $0.05(0.013)$ & $0.01(0.005)$ & $3.41(0.722)$ & $0.04(0.008)$ & $10.6(1.2)$ \\
\hline Norsminde Fjord & $1.49(0.15)$ & 26.31 (1.49) & $0.01(0.004)$ & $0.00(0.001)$ & $0.02(0.003)$ & $0.00(0.001)$ & $-0.5(0.6)$ \\
\hline
\end{tabular}


the sieved sediment from Randers Fjord. However, there was no accumulation of ${ }^{30} \mathrm{~N}_{2}$. This pattern was reproducible, as shown in the time-series experiments performed in the second phase of the study (Fig. 1). In the sediment from Norsminde Fjord, there was no accumulation of ${ }^{29} \mathrm{~N}_{2}$ or ${ }^{30} \mathrm{~N}_{2}$ in the ${ }^{15} \mathrm{NH}_{4}{ }^{+}+{ }^{14} \mathrm{NO}_{3}{ }^{-}$-amended slurries (Table 2).

The contribution of anammox to total $\mathrm{N}_{2}$ production was 6.2 and $10.6 \%$ in the intact and sieved Randers Fjord sediment, respectively, in the Phase 1 experiments. The contribution of anammox to $\mathrm{N}_{2}$ production in Norsminde was below detection limit.

Volume-specific anammox activity estimated from slurry incubations of sediment from Randers Fjord was highest in April (ANOVA, p = 0.01), whereas no significant difference was seen between rates obtained in
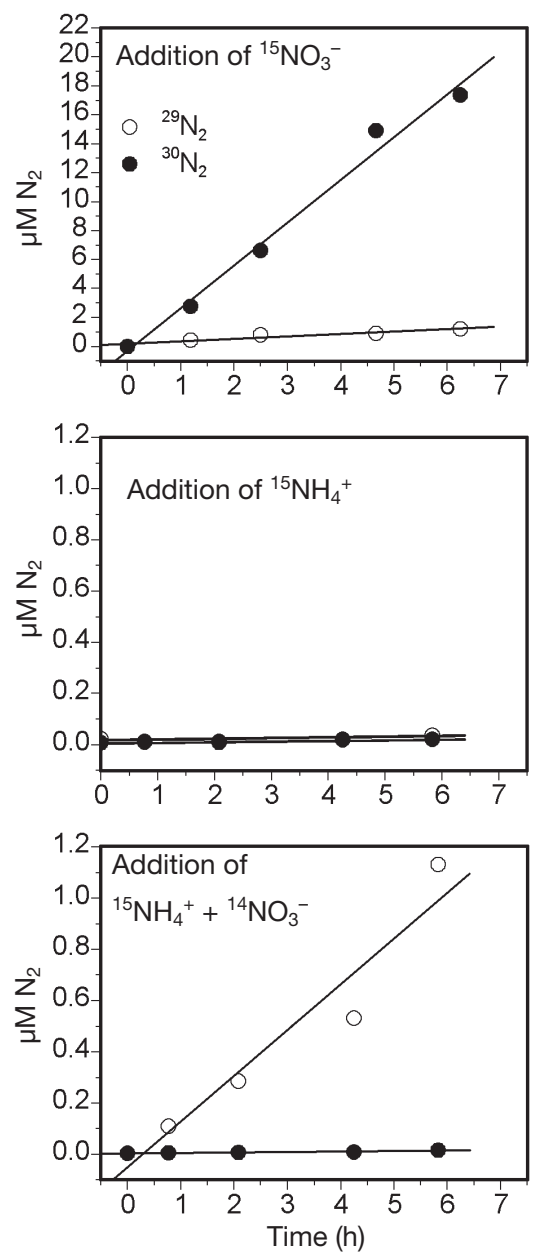

Fig. 1. Examples of concentrations of ${ }^{29} \mathrm{~N}_{2}$ and ${ }^{30} \mathrm{~N}_{2}$ in samples incubated with either ${ }^{15} \mathrm{NO}_{3}{ }^{-},{ }^{15} \mathrm{NH}_{4}{ }^{+}$or ${ }^{14} \mathrm{NO}_{3}{ }^{-}$and ${ }^{15} \mathrm{NH}_{4}{ }^{+}$ during Phase 2 of study (April, June, September 2003)
Table 3. Volume-specific rates of anammox and denitrification estimated from slurry incubations with either ${ }^{15} \mathrm{NO}_{3}{ }^{-}$or ${ }^{15} \mathrm{NO}_{2}{ }^{-}$, contribution of anammox to $\mathrm{N}_{2}$ production ( $\mathrm{ra}$ ), and in situ temperature plus bottom-water concentrations of $\mathrm{NO}_{3}{ }^{-}+\mathrm{NO}_{2}^{-}\left(\mathrm{NO}_{\mathrm{x}}^{-}\right)$. Values are means (SE), $\mathrm{n}=4$. Data are from Phase 2 of study (2003)

\begin{tabular}{|lccrrr|}
\hline Month & $\begin{array}{c}\text { Anammox } \\
\left(\mathrm{nmol} \mathrm{N} \mathrm{cm}{ }^{-3} \mathrm{~h}^{-1}\right)\end{array}$ & $\begin{array}{c}\text { Denitrification } \\
\left(\mathrm{nmol} \mathrm{N} \mathrm{cm}^{-3} \mathrm{~h}^{-1}\right)\end{array}$ & $\begin{array}{c}\mathrm{ra} \\
(\%)\end{array}$ & $\begin{array}{c}\mathrm{NO}_{\mathrm{x}}^{-} \\
(\mu \mathrm{M})\end{array}$ & $\begin{array}{c}\mathrm{T} \\
\left({ }^{\circ} \mathrm{C}\right)\end{array}$ \\
\hline April & $11(0.2)$ & $31(1)$ & 26.4 & 120 & 11 \\
June & & $137(8)$ & 3.7 & & 16 \\
$\mathrm{NO}_{3}^{-}$ & $5.2(1.3)$ & $131(5.7)$ & 4.3 & & \\
$\mathrm{NO}_{2}^{-}$ & $5.9(0.3)$ & $72(8)$ & 5.0 & 15 & 20 \\
$\begin{array}{l}\text { August } \\
\mathrm{NO}_{3}^{-}\end{array}$ & $3.8(0.6)$ & $69(3.8)$ & 5.5 & & \\
$\mathrm{NO}_{2}^{-}$ & $4.1(1.5)$ & & & & \\
\hline
\end{tabular}

June and August (Table 3, ANOVA, p = 0.6). Volumespecific denitrification rates were highest in June and lowest in April (Table 3, ANOVA, $\mathrm{p}=0.01$ ). Accordingly, the contribution of anammox to $\mathrm{N}_{2}$ production varied over the period investigated: anammox contributed approximately $26 \%$ in April, whereas the contribution from anammox in August was only $5 \%$. There was no significant difference between rates obtained with $\mathrm{NO}_{3}{ }^{-}$or $\mathrm{NO}_{2}{ }^{-}$as substrate in either denitrification or anammox activities (ANOVA, p > 0.5; Table 3).

\section{Phylogenetic analysis and detection of anammox bacteria}

Phylogenetic analysis showed that the 16S rRNA sequence amplified from DNA extracted from the Randers Fjord sediment was affiliated with the anammox organism candidatus Scalindua sorokinii (Fig. 2). The overall sequence similarity to candidatus $S$. sorokinii was about $99 \%$. FISH demonstrated that the organisms affiliated with candidatus $S$. sorokinii/candidatus $S$. wagneri were the only detectable anammox bacteria in the sample (Fig. 3). No other Planctomycetes were detected.

\section{Porewater profiles}

Average $\mathrm{O}_{2}$ and $\mathrm{NO}_{\mathrm{x}}{ }^{-}$concentration profiles and depth-specific rates of $\mathrm{O}_{2}$ and $\mathrm{NO}_{\mathrm{x}}{ }^{-}$production calculated from porewater profiles are shown in Figs. 4 \& 5 . In sediment cores from Randers Fjord, zones of $\mathrm{NO}_{\mathrm{x}}^{-}$ production and consumption zones were separated at the oxic/suboxic interface. A very high production of oxygen by benthic microalgae in the top $0.3 \mathrm{~mm}$ of the sediment from Randers Fjord caused $\mathrm{O}_{2}$ and $\mathrm{NO}_{\mathrm{x}}{ }^{-}$penetration depths to increase by more than $1 \mathrm{~mm}$ during illumination. Despite these changes there was no sig- 


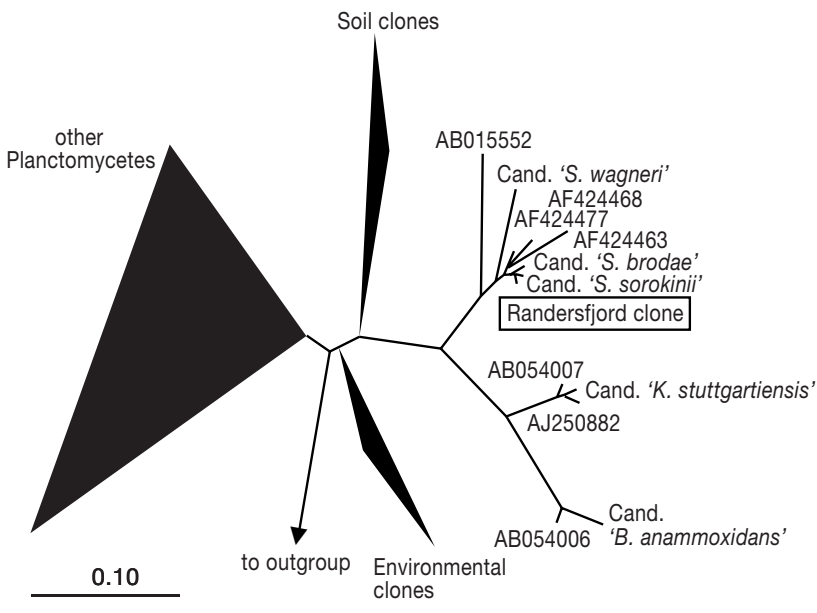

Fig. 2. Phylogenetic tree reflecting relationship of 16S rRNA sequence type amplified from Randers Fjord, other anammox organisms, other members of the order Planctomycetes and other reference organisms. Phylogenetic analyses were performed with maximum likelihood, neighbor-joining and maximum parsimony methods with $50 \%$ conservation filters for Bacteria and Planctomycetes. Triangles indicate phylogenetic groups. S., K., B. represent genus names Scalindua, Kuenenia and Brocadia, respectively

nificant difference in net $\mathrm{NO}_{\mathrm{x}}{ }^{-}$consumption/production rates in light and darkness (Student's $t$-test, $\mathrm{p}>$ $0.2)$. In the sieved sediment, the distribution of $\mathrm{NO}_{\mathrm{x}}{ }^{-}$ production and consumption zones relative to the oxic/ suboxic interface was similar to that found in natural cores from Randers Fjord. However, the rates of the $\mathrm{NO}_{\mathrm{x}}{ }^{-}$transformation processes were higher (Fig. 5).

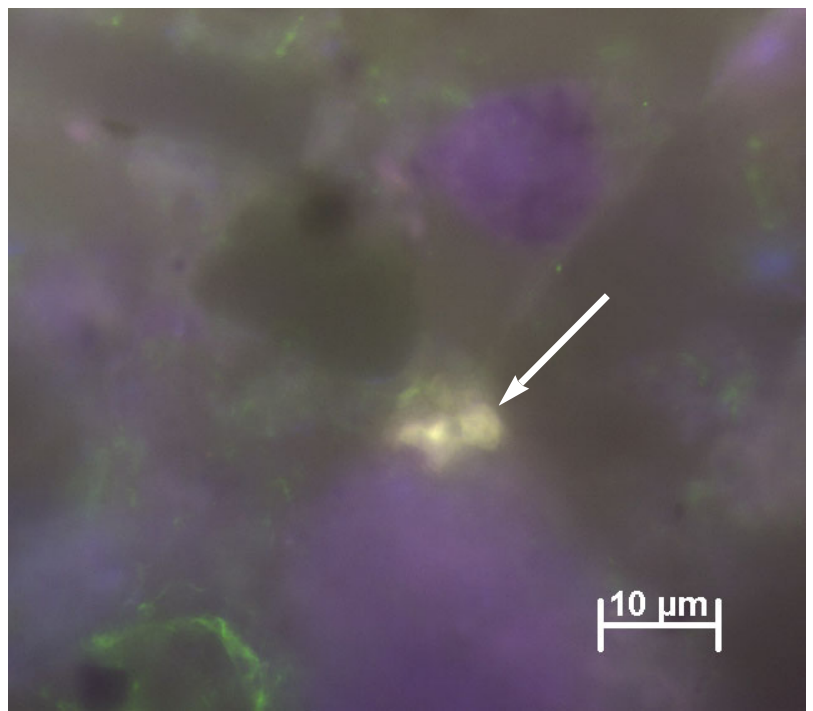

Fig. 3. Fluorescence in situ hybridization of Randers Fjord sediment; arrow indicates candidatus Scalindua sorokiniirelated cells, which appear whitish yellow because of triple hybridization of S-*-Amx-0368-a-A-18 (labeled with Cy3, red), S-*-BS-0820-a-A-22 (labeled with Fluos green) and S-P-Planc-0046-a-A-18 (labeled with Cy5)

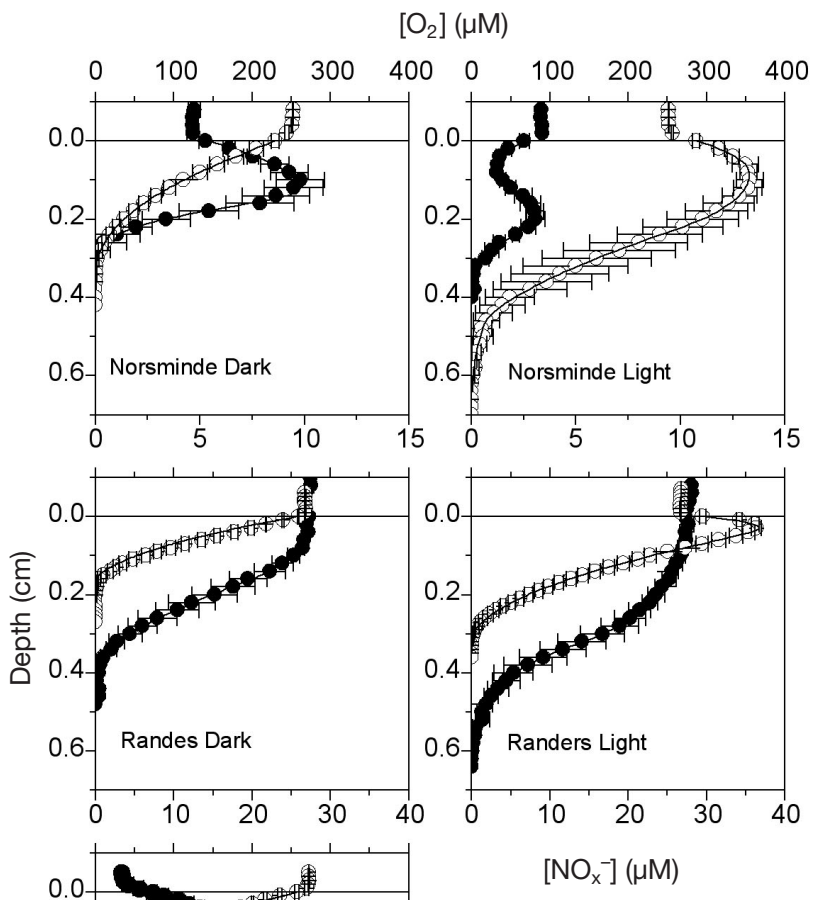

Fig. 4. Microprofiles of $\mathrm{O}_{2}(\mathrm{O})$ and $\mathrm{NO}_{\mathrm{x}}^{-}(\bullet)$. Circles: means; error bars: SEs; lines: concentration profiles estimated from numerical simulations

Porewater profiles in dark-incubated cores from Norsminde Fjord showed distinct zones of $\mathrm{NO}_{\mathrm{x}}{ }^{-}$production and consumption. Net $\mathrm{NO}_{\mathrm{x}}^{-}$production was lowest in light (Student's $t$-test, $\mathrm{p}=0.03$ ) whereas no significant difference was seen in net $\mathrm{NO}_{\mathrm{x}}{ }^{-}$consumption rates measured in darkness and in light (Student's $t$-test, $\mathrm{p}=0.07)$. In contrast to the other sediments, oxygen and $\mathrm{NO}_{\mathrm{x}}{ }^{-}$were depleted at approximately the same depth $(0.3 \mathrm{~mm})$, and $\mathrm{NO}_{\mathrm{x}}{ }^{-}$was consumed in the oxic zone well above the oxic/suboxic interface during both illumination and darkness (Fig. 4). A control experiment showed that $\mathrm{N}_{2}$ was produced only in the absence of $\mathrm{O}_{2}$ (data not shown), and $\mathrm{NO}_{\mathrm{x}}{ }^{-}$consumption in the oxic zone was therefore not due to aerobic denitrification but most probably to microphytobenthic $\mathrm{N}$-assimilation.

\section{Total and diffusive $\mathbf{N}_{2}$ production rates}

Area-based rates of anammox and denitrification estimated from the porewater profiles of $\mathrm{NO}_{\mathrm{x}}{ }^{-}$, the IPT and the revised IPT are shown in Table $4 . \mathrm{N}_{2}$ produc- 


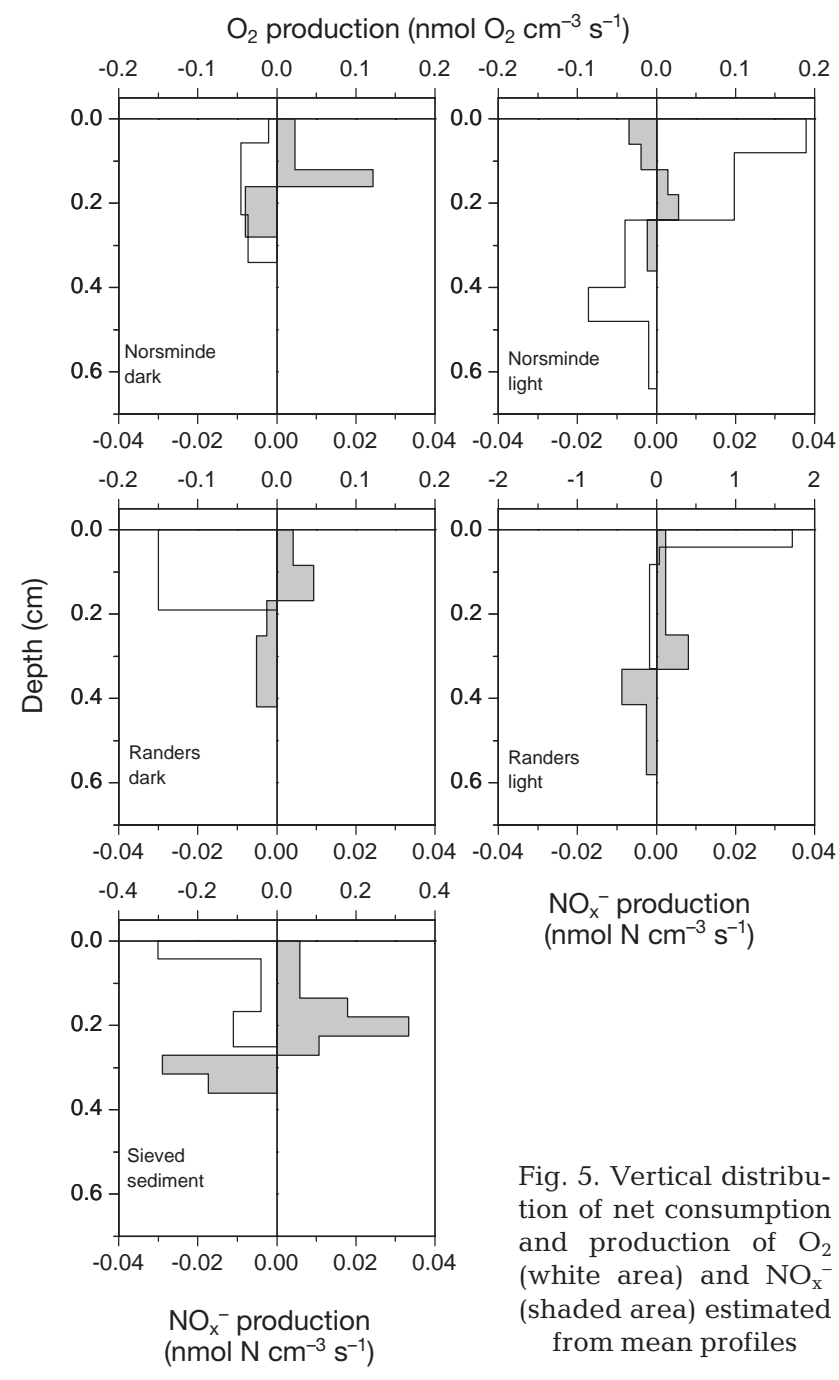

tion rates estimat ed with the IPT were not statistically different from the rates estimated with the revised technique. Likewise, no significant difference was seen between rates measured during illumination and during darkness (Student's $t$-test, $\mathrm{p}>0.1$ ). On a diurnal scale, $\mathrm{N}_{2}$ production rates estimated with ${ }^{15} \mathrm{~N}$ isotopes in Norsminde Fjord were similar to the activity measured in Randers Fjord (Student's $t$-test, $\mathrm{p}=0.48$ ). $\mathrm{N}_{2}$ production estimated from porewater profiles in the intact sediment from Randers Fjord was less than $20 \%$ of the activity measured with ${ }^{15} \mathrm{~N}$ isotopes. The discrepancy was even more pronounced in the sediment from Norsminde Fjord, where porewater profiles showed that $\mathrm{NO}_{\mathrm{x}}^{-}$did not penetrate to the suboxic layers of the sediment, indicating absence of denitrification activity, although the IPT revealed high $\mathrm{N}_{2}$ production rates. $\mathrm{N}_{2}$ production rates estimated from the porewater profiles in the sieved and defaunated Randers Fjord sediment were not significantly different (Student's $t$-test, $\mathrm{p}=0.47 \%$ ), however, from the estimates based on the revised IPT applied to the same sediment.

\section{Exchange of $\mathrm{O}_{2}$ and $\mathrm{NO}_{\mathrm{x}}^{-}$between sediment and water column}

Exchange rates of $\mathrm{O}_{2}$ and $\mathrm{NO}_{\mathrm{x}}{ }^{-}$estimated from porewater profiles and from flux-core measurements are shown in Table 5. Whole-core measurements showed a consistent net uptake of $\mathrm{O}_{2}$ in all cores at all times, whereas microsensor profiles indicated net efflux of oxygen during illumination. In darkness, the total $\mathrm{O}_{2}$ uptake was about 7 (Randers) and about 20 (Norsminde) times higher than the diffusive uptake estimated from porewater profiles. A similar discrepancy was observed for $\mathrm{NO}_{\mathrm{x}}^{-}$fluxes, which also showed a consistent net uptake of $\mathrm{NO}_{\mathrm{x}}{ }^{-}$in all undisturbed sediments when measured from whole cores. Porewater profiles, on the other hand, indicated a small efflux of $\mathrm{NO}_{\mathrm{x}}{ }^{-}$from sediment cores from Randers Fjord in both light and darkness. In the sediment from Norsminde Fjord, porewater profiles suggested efflux of $\mathrm{NO}_{\mathrm{x}}^{-}$

Table 4. $\mathrm{N}_{2}$ production rates $\left(\mu \mathrm{molN} \mathrm{m}{ }^{-2}\right.$ ) estimated with $\mathrm{NO}_{\mathrm{x}}{ }^{-}$microsensors (diffusive $\mathrm{N}_{2}$ production) and from whole-core incubations with ${ }^{15} \mathrm{NO}_{3}{ }^{-}$(total $\mathrm{N}_{2}$ production). Values are means (SE), $\mathrm{n}=5$. IPT: isotope pairing technique

\begin{tabular}{|c|c|c|c|c|c|c|c|c|c|}
\hline \multirow[t]{2}{*}{ Site } & \multicolumn{3}{|c|}{ Diffusive $\mathrm{N}_{2}$ production } & \multicolumn{3}{|c|}{ Total $\mathrm{N}_{2}$ production - IPT } & \multicolumn{3}{|c|}{ Total $\mathrm{N}_{2}$ production - revised IPT } \\
\hline & $\begin{array}{l}\text { Anaerobic } \mathrm{NO}_{3}^{-} \\
\text {reduction }\end{array}$ & Anammox & Denitrification & $\mathrm{N}_{2}$ prod. & Anammox & Denitrification & $\mathrm{N}_{2}$ prod. & Anammox & Denitrification \\
\hline \multicolumn{10}{|l|}{ Randers Fjord } \\
\hline Light & $43.2(1.8)$ & $4.7(0.2)$ & $39.8(1.7)$ & $238(43.0)$ & $14.8(2.7)$ & $223(40)$ & $233(42)$ & $14.0(2.5)$ & $219(40)$ \\
\hline Dark & $50.1(3.9)$ & $5.5(0.4)$ & $46.2(3.6)$ & 365 (49) & $23(3.1)$ & $342(46)$ & 356 (48) & $21(2.9)$ & $335(46)$ \\
\hline $\begin{array}{l}\text { Randers Fjord } \\
\text { (sieved) }\end{array}$ & $77.8(4.2)$ & $8.7(0.5)$ & $73.4(4.0)$ & $97(3.1)$ & $10(0.3)$ & $87(2.7)$ & $91(2.5)$ & $9.6(0.3)$ & $81(2.3)$ \\
\hline \multicolumn{10}{|c|}{ Norsminde Fjord } \\
\hline Light & 0.0 & 0.0 & 0.0 & $236(32)$ & 0.0 & $236(32)$ & $236(32)$ & 0.0 & $236(32)$ \\
\hline Dark & 0.0 & 0.0 & 0.0 & $191(38)$ & 0.0 & $191(38)$ & $191(38)$ & 0.0 & $191(38)$ \\
\hline
\end{tabular}


Table 5. Oxygen and $\mathrm{NO}_{\mathrm{x}}^{-}$exchange rates $\left(\mu \mathrm{molN} \mathrm{m} \mathrm{N}^{-2} \mathrm{~h}^{-1}\right)$ estimated with microsensors (Diffusive) and from whole-core incubations (Total). Values are means (SE), $\mathrm{n}=5$

\begin{tabular}{|lcccc|}
\hline \multicolumn{2}{|c}{ Site } & \multicolumn{4}{c|}{$\mathrm{O}_{2}$} & \multicolumn{2}{c|}{$\mathrm{NO}_{\mathrm{x}}^{-}$} \\
& Diffusive & Total & Diffusive & Total \\
\hline $\begin{array}{l}\text { Randers Fjord } \\
\text { Light }\end{array}$ & $1932(112)$ & $-3021(623)$ & $1.6(1.4)$ & $-47(15)$ \\
Dark & $-950(89)$ & $-7193(399)$ & $4.5(2.3)$ & $-68.0(23.0)$ \\
$\begin{array}{l}\text { Randers Fjord } \\
\text { (sieved) }\end{array}$ & $-788(66)$ & $-727(39)$ & $54(3.8)$ & $44(4)$ \\
$\begin{array}{l}\text { Norsminde Fjord } \\
\text { Light }\end{array}$ & $510(113)$ & $-2192(2023)$ & $-12(1.9)$ & $-120(36)$ \\
Dark & $-515(38)$ & $-11123(497)$ & $20(4.7)$ & $-51(23)$ \\
\hline
\end{tabular}

in the dark and uptake in light at a rate more than 10 times lower than the uptake measured in whole cores. In contrast to the natural sediments, neither $\mathrm{O}_{2}$ nor $\mathrm{NO}_{\mathrm{x}}{ }^{-}$fluxes measured in whole cores prepared from sieved sediment were significantly different from equivalent parameters estimated from porewater profiles (Student's $t$-test, $\mathrm{p}=0.2$; Table 5).

\section{DISCUSSION}

\section{Presence and absence of anammox in estuarine sediment}

In our search for alternative $\mathrm{N}_{2}$-producing processes, we found evidence of anaerobic $\mathrm{NH}_{4}{ }^{+}$oxidation in the presence of $\mathrm{NO}_{3}{ }^{-}$in slurries prepared with sediment from Randers Fjord (Table 1). The lack of ${ }^{15} \mathrm{~N}-\mathrm{N}_{2}$ accumulation in samples from both fjords incubated with only ${ }^{15} \mathrm{NH}_{4}{ }^{+}$excludes the possibility of coupled nitrification-denitrification, which might have occurred if $\mathrm{O}_{2}$ had been introduced into the slurries by mistake at the beginning of the experiment. Anaerobic oxidation of $\mathrm{NH}_{4}{ }^{+}$to $\mathrm{NO}_{\mathrm{x}}{ }^{-}$or $\mathrm{N}_{2}$ with, for instance, $\mathrm{MnO}_{2}$ (Luther et al. 1997, Hulth et al. 1999) can also be excluded. If this process was significant, $\mathrm{NO}_{\mathrm{x}}^{-}$produced through oxidation of $\mathrm{NH}_{4}{ }^{+}$would undergo denitrification and result in accumulation of ${ }^{15} \mathrm{~N}-\mathrm{N}_{2}$ gas in the slurries amended with ${ }^{15} \mathrm{NH}_{4}{ }^{+}$only. As mentioned above, no such accumulation was observed.

Accumulation of ${ }^{15} \mathrm{~N}-\mathrm{N}_{2}$ in the ${ }^{15} \mathrm{NH}_{4}{ }^{+}+{ }^{14} \mathrm{NO}_{3}{ }^{-}-$ amended Randers Fjord sediments is the result of 1 of the following 2 reactions:

$$
\begin{gathered}
{ }^{15} \mathrm{NH}_{4}{ }^{+}+{ }^{14} \mathrm{NO}_{2}{ }^{-} \rightarrow{ }^{29} \mathrm{~N}_{2}+2 \mathrm{H}_{2} \mathrm{O} \\
5^{15} \mathrm{NH}_{4}{ }^{+}+3^{14} \mathrm{NO}_{3}{ }^{-} \rightarrow \\
3^{29} \mathrm{~N}_{2}+{ }^{30} \mathrm{~N}_{2}+9 \mathrm{H}_{2} \mathrm{O}+2 \mathrm{H}^{+}
\end{gathered}
$$

(Reaction 1)

(Reaction 2)

The lack of a 3:1 ratio between ${ }^{29} \mathrm{~N}_{2}$ and ${ }^{30} \mathrm{~N}_{2}$ production in the ${ }^{15} \mathrm{NH}_{4}{ }^{+}+{ }^{14} \mathrm{NO}_{3}{ }^{-}$-amended slurries (Table 2,
Fig. 3) excludes Reaction 2 and points to Reaction 1, which is identical to the anammox reaction according to Strous et al. (1999). Thus, our data are strong proof of the presence of the anammox process in sediment from Randers Fjord. Furthermore, our data show that anaerobic $\mathrm{NO}_{2}^{-}$generation rates were sufficiently high in this sediment to provide the bacteria with enough substrate for the reaction, as indicated by the fact that anammox rates measured with ${ }^{15} \mathrm{NO}_{3}{ }^{-}$and with ${ }^{15} \mathrm{NO}_{2}{ }^{-}$ were similar (Table 3).

Autotrophic bacteria of the phylum Planctomycetes have been shown to be responsible for the anammox process (Strous et al. 1999, Schmid et al. 2000, 2003), and recently occurrence of anammox in the anoxic water column of the Black Sea was associated with the presence of a newly discovered Planctomycetes species candidatus Scalindua sorokinii (Kuypers et al. 2003). Phylogenetic analysis of $16 \mathrm{~S}$ rRNA gene sequences amplified from DNA extracted from the Randers Fjord sediment showed a close relationship to candidatus S. sorokinii (Fig. 2). FISH analysis of sediment samples from Randers Fjord also showed the presence of small clusters of cells belonging to candidatus S. sorokinii (Fig. 3), confirming further that the bacteria belonging to the phylum Planctomycetes found in the Randers Fjord sediment were all affiliated with candidatus $S$. sorokinii. Since the FISH and the ${ }^{15} \mathrm{~N}$ isotope data are consistent, the present study confirms the link between presence of bacteria affiliated with candidatus $S$. sorokinii and the anammox reaction in marine environments observed by Kuypers et al. (2003) in the Black Sea. It is remarkable that so closely related species are present in so distantly related environments as the anoxic water column of the Black Sea and the Randers Fjord sediment. However, this finding is in line with the classical view of Beijerinck (Brock 1961) that any bacterial species can occur anywhere, provided its environmental requirements are met, due to the enormous microbial population sizes that result in high dispersal probability and low probability of local extinction (Finlay \& Clarke 1999, Fenchel 2003).

Our failure to demonstrate the existence of anammox in Norsminde Fjord (Table 2) indicates that the anammox process is not ubiquitous. We propose that the existence of anammox in the surface sediment of Randers Fjord and the absence of the process from Norsminde Fjord may be linked to differences in the availability of $\mathrm{NO}_{\mathrm{x}}^{-}$in the suboxic zone of the sediment. At the study site in Randers Fjord the watercolumn $\mathrm{NO}_{\mathrm{x}}^{-}$concentration is always above $15 \mu \mathrm{M}$ (County of Aarhus 1999, Nielsen et al. 2001), and nitrification rates are high (Nielsen et al. 2001). Porewater profiles of $\mathrm{NO}_{\mathrm{x}}{ }^{-}$measured in the surface sediment furthermore showed that $\mathrm{NO}_{\mathrm{x}}^{-}$penetrates into the suboxic zone, where it is consumed (Fig. 4). In contrast, 
water-column $\mathrm{NO}_{\mathrm{x}}{ }^{-}$is depleted in Norsminde Fjord during the summer months (Nielsen et al. 1995), and assimilation by benthic microalgae can prevent penetration of $\mathrm{NO}_{\mathrm{x}}{ }^{-}$into the suboxic zone of the sediment (Fig. 4), probably because the supply of $\mathrm{NO}_{\mathrm{x}}{ }^{-}$from the water column is low (see for instance Meyer et al. 2001). According to current knowledge, anammox bacteria are slow-growing obligate anaerobes and base their energy production solely on $\mathrm{NO}_{2}{ }^{-}$and $\mathrm{NH}_{4}{ }^{+}$ conversion (Strous et al. 1999). In contrast, most denitrifying bacteria are organotrophic organisms capable of using $\mathrm{O}_{2}$ as an electron acceptor (Zumft 1992). Thus, denitrifying bacteria seem better adapted to the fluctuating availability of $\mathrm{O}_{2}$ and $\mathrm{NO}_{\mathrm{x}}^{-}$imposed by microalgae. Experimental studies of anammox and denitrification in sediments with and without microphytobenthic activity confirm this hypothesis (R. L. Meyer \& N. Risgaard-Petersen unpubl.). Nitrite porewater profiles furthermore indicate that net $\mathrm{NO}_{2}{ }^{-}$production takes place mainly in the suboxic zone of the sediment as a result of $\mathrm{NO}_{3}{ }^{-}$reduction (Stief et al. 2002). This may indicate that anammox bacteria are dependent on release of $\mathrm{NO}_{2}{ }^{-}$from anaerobic $\mathrm{NO}_{3}{ }^{-}$reducers such as denitrifying bacteria. If $\mathrm{NO}_{3}{ }^{-}$availability is low, as in Norsminde Fjord during the summer months, the loss of $\mathrm{NO}_{2}^{-}$from denitrifiers would probably be insignificant and insufficient to support a population of anammox bacteria.

\section{Importance of anammox as an $\mathrm{N}_{2}$ source in Randers Fjord}

In the surface sediment of Randers Fjord we observed the highest volume-specific anammox rates in April and the lowest in September 2003, suggesting that the activity of anammox bacteria decreases during the course of the summer period. Denitrification did not follow a similar trend, and as a consequence the contribution of anammox to $\mathrm{N}_{2}$ production decreased from 26 to $5 \%$. This indicates seasonal variations in the abundance of the respective bacterial groups and that denitrifying bacteria and anammox bacteria are controlled in different ways. The observed indications of seasonal fluctuations in the contribution of anammox to $\mathrm{N}_{2}$ production probably reflect differences in the availability of organic carbon and $\mathrm{NO}_{\mathrm{x}}{ }^{-}$over the season. In the summer months, $\mathrm{O}_{2}$ consumption rates in Randers Fjord are generally higher than during spring and winter (Nielsen et al. 2001). This may indicate that the availability of organic carbon is higher and that conditions are more favorable for the organotrophic denitrifying bacteria than for the lithotrophic anammox bacteria in the sediments during the summer period.
The volume-specific anammox activity measured in Randers Fjord was close to the activity measured in the Skagerrak (5 nmolN cm$\left.{ }^{-3} \mathrm{~h}^{-1}\right)$ at Stn S9 at the temperature applied in the present study $\left(16^{\circ} \mathrm{C}\right)$ (see Dalsgaard \& Thamdrup 2002) and within the range reported by Trimmer et al. (2003) for the Thames Estuary ( 0.2 to $10 \mathrm{nmolN} \mathrm{cm}^{-3} \mathrm{~h}^{-1}$ ). This may be an indication that population densities of anammox bacteria in Randers Fjord, Skagerrak and Thames sediments are comparable. Despite these similarities, anammox in Randers Fjord and the Thames is relatively less important as a source of $\mathrm{N}_{2}$ production ( $r a=5$ to $25 \%$ in Randers Fjord [Tables $2 \& 3$ ] and 1 to $8 \%$ in the Thames Estuary) than in the Skagerrak sediment, where the process accounts for ca. $70 \%$ of $\mathrm{N}_{2}$ production (Thamdrup \& Dalsgaard 2002). Volume-specific denitrification rates in Randers Fjord exceeded the rates in the Skagerrak by a factor of 15 in April and a factor of 30 in August. The Randers Fjord sediment thus seemed to be a more favorable habitat for denitrifying bacteria than the Skagerrak sediment, which explains the difference in contribution of anammox to $\mathrm{N}_{2}$ production. This is not surprising, as it is well known that benthic carbon mineralization rates decrease with increasing water depth (Canfield 1993) due to a decrease in easily degradable carbon. The Skagerrak sediment (water depth $695 \mathrm{~m}$ ) would thus be expected to have a much lower heterotrophic microbial activity than the shallow Randers Fjord (water depth ca. $1 \mathrm{~m}$ ), which is furthermore heavily eutrophic. The difference in overall heterotrophic activity between Randers Fjord and the Skagerrak is reflected both in the $\mathrm{O}_{2}$ penetration depth and in the sediment $\mathrm{O}_{2}$ uptake rate. The $\mathrm{O}_{2}$ penetration depth in the Skagerrak sediment is $1.5 \mathrm{~cm}$ and the sediment $\mathrm{O}_{2}$ consumption rate $4 \mathrm{mmol} \mathrm{m} \mathrm{m}^{-2} \mathrm{~d}^{-1}$ (Rysgaard et al. 2001), which is 10 times higher and 150 times lower, respectively, than the equivalent parameters measured in darkness in Randers Fjord in the present study.

\section{Anammox and denitrification in cores with natural substrate gradients}

Sediment anammox rates presented in the literature (Dalsgaard \& Thamdrup 2002, Thamdrup \& Dalsgaard 2002, Trimmer et al. 2003) are at best potential rates, being estimated with methods that disrupt the natural substrate gradients in the sediment. In the present study, we applied ${ }^{15} \mathrm{~N}$ and microsensor techniques to estimate anammox activity in sediments with intact stratification. The applied ${ }^{15} \mathrm{~N}$ calculation procedures - the IPT (Nielsen 1992) and the revised IPT (Risgaard-Petersen et al. 2003) — yielded similar esti- 
mates of anammox and denitrification rates (Table 4) because the contribution of anammox to $\mathrm{N}_{2}$ production was too low to seriously affect the assumptions underlying the IPT (Risgaard-Petersen et al. 2003). Using the revised IPT on ${ }^{15} \mathrm{~N}_{2}$ raw data from Rysgaard et al. (2001), Risgaard-Petersen et al. (2003) estimated an anammox rate of $4 \mu \mathrm{molN} \mathrm{m}{ }^{-2} \mathrm{~h}^{-1}$ in the Skagerrak sediment studied by Thamdrup \& Dalsgaard (2002). This is between 18 and $29 \%$ of the rates estimated in Randers Fjord with ${ }^{15} \mathrm{~N}$ isotopes (Table 4). The anammox process is thus quantitatively more important in the Randers Fjord sediment than in the Skagerrak.

We observed a large difference between the estimates of denitrification and anammox obtained with microsensors and those obtained with ${ }^{15} \mathrm{~N}$ isotopes (Table 4). $\mathrm{N}_{2}$ production rates estimated from interpretation of porewater profiles were 22 and $0 \%$ of the $\mathrm{N}_{2}$ production rates obtained with ${ }^{15} \mathrm{~N}$ isotopes in the Randers Fjord and the Norsminde Fjord sediments, respectively. A similar difference was observed when total and diffusive $\mathrm{O}_{2}$ and $\mathrm{NO}_{\mathrm{x}}{ }^{-}$uptake rates were compared (Table 5). This discrepancy was probably due to the presence of fauna, because the applied ${ }^{15} \mathrm{~N}$ technique captures total $\mathrm{N}_{2}$ production, while the microsensor technique only captures the diffusioncontrolled $\mathrm{N}_{2}$ production at the sediment surface. This hypothesis is supported by the consistent agreement found between the methods regarding all parameters measured in the sieved and defaunated sediment from Randers Fjord (Tables 4 \& 5). Furthermore, the hypothesis is fully in line with conclusions from previous studies comparing diffusive $\mathrm{O}_{2}$ or $\mathrm{N}_{2} \mathrm{O}$ fluxes estimated from microsensor profiles and total exchange rates in impermeable sediments (Andersen \& Helder 1987, Binnerup et al. 1992, Glud et al. 1994, Berg et al. 2001). The mechanisms responsible for this fauna-mediated stimulation of biogeochemical processes include enhanced porewater transport caused by biodiffusion and irrigation as well as a several-fold increase in the area of the oxic/suboxic interface in the presence of polychaete burrows (Kristensen 2000 \& references therein). Several experimental studies addressing the impact of benthic animals on the $\mathrm{N}$-cycle processes have shown that via these mechanisms benthic fauna may significantly stimulate benthic $\mathrm{N}_{2}$ production (e.g. Binnerup et al. 1992, Pelegri et al. 1994, Svensson et al. 2001, Newell et al. 2002).

Acknowledgements. We thank Anna Haxen, Kitte Gerlich, Egon Frandsen and Marlene Jessen for assistance in the laboratory. This study was in part supported by grants from the Danish Natural Science Research Councils (Contract No. 5100-0458 and Contract No. 51-00-0320) and in part by the ICON project under the European Union 5th Framework Programme, Project No. EVK1-CT2000-00054.

\section{LITERATURE CITED}

Aller RC (1982) The effects of macrobenthos on chemical properties of marine sediment and overlying water. In: McCall PL, Tevesz PJS (eds) Animal-sediment relations. Plenum, New York, p 53-102

Aller RC, Aller JY (1998) The effect of biogenic irrigation intensity and solute exchange on diagenetic reaction rates in marine sediments. J Mar Res 56:905-936

Andersen FØ, Helder W (1987) Comparison of oxygen microgradients, oxygen flux rates and electron transport system activity in coastal marine sediments. Mar Ecol Prog Ser 37: 259-264

Berg P, Risgaard-Petersen N, Rysgaard S (1998) Interpretation of measured concentration profiles in sediment pore water. Limnol Oceanogr 43:1500-1510

Berg P, Rysgaard S, Funch P, Sejr MK (2001) Effects of bioturbation on solutes and solids in marine sediments. Aquat Microb Ecol 26:81-94

Binnerup SJ, Jensen K, Revsbech NP, Jensen MH, Sørensen J (1992) Denitrification, dissimilatory reducton of nitrate to ammonia and nitrification in a bioturbated estuarine sediment as measured with ${ }^{15} \mathrm{~N}$ and microsensor techniques. Appl Environ Microbiol 58:303-313

Boudreau BP (1997) Diagenetic models and their implementation. Springer-Verlag, Berlin

Braman RS, Hendrix SA (1989) Nanogram nitrite and nitrate determination in environmental and biological materials by vanadium (III) reduction with chemiluminescence detection. Analyt Chem 61:2715-2718

Brock TD (1961) Milestones in microbiology. Prentice-Hall, Englewood Cliffs, NJ

Canfield D (1993) Organic matter oxidation in marine sediments. In: Wollast R, Mackenzie FT, Chou L (eds) Interactions of C, N, P and S biogeochemical cycles. SpringerVerlag, Berlin, p 333-363

County of Aarhus (1994) Norsminde Fjord 1992. Natur og Miljø Århus Amt, Århus

County of Aarhus (1999) Randers Fjord status 1997. Natur og Miljø Århus Amt, Århus

Dalsgaard T, Thamdrup B (2002) Factors controlling anaerobic ammonium oxidation with nitrite in marine sediments. Appl Environ Microbiol 68:3802-3808

Dalsgaard T, Nielsen LP, Brotas V, Viaroli P and 10 others (2000) Protocol handbook for NICE - nitrogen cycling in estuaries: a project under the EU research programme: marine science and technology (MAST III). National Environmental Research Institute, Silkeborg

Devol AH (1991) Direct measurements of nitrogen gas fluxes from continental shelf sediments. Nature 349:319-321

Devol AH (2003) Nitrogen cycle - solution to a marine mystery. Nature 422:575-576

Fenchel TB (2003) Biogeography for bacteria. Science 301: 925-926

Finlay BJ, Clarke KL (1999) Ubiquitous dispersal of microbial species. Nature 400:828

Fütterer DF (2000) The solid phase of marine sediments. In: Schulz HD, Zabel M (eds) Marine geochemistry. SpringerVerlag, Berlin, p 1-22

Glud RN, Gundersen JK, Jørgensen BB, Revsbech NP, Schulz HD (1994) Diffusive and total oxygen uptake of deep-sea sediments in the eastern South Atlantic Ocean: in situ and laboratory measurements. Deep-Sea Res 41:1767-1788

Glud RN, Forster S, Huettel M (1996) Influence of radial pressure gradients on solute exchange in stirred benthic chambers. Mar Ecol Prog Ser 141:303-311

Grasshoff K, Erhardt M, Kremling K (1983) Methods of sea- 
water analysis. Verlag Chemie, Weinheim

Hulth S, Aller RC, Gilbert F (1999) Coupled anoxic nitrification manganese reduction in marine sediments. Geochim Cosmochim Acta 63:49-66

Jensen K, Revsbech NP, Nielsen LP (1993) Microscale distribution of nitrification activity in sediment determined with a shielded microsensor for nitrate. Appl Environ Microbiol 59:3287-3296

Jensen K, Sloth NP, Risgaard-Petersen N, Rysgaard S, Revsbech NP (1994) Estimation of nitrification and denitrification from microprofiles of oxygen and nitrate in model sediment systems. Appl Environ Microbiol 60:2094-2100

Kristensen E (2000) Organic matter diagenesis at the oxic/ anoxic interface in coastal marine sediments, with emphasis on the role of burrowing animals. Hydrobiologia 426: $1-24$

Kuypers MMM, Sliekers AO, Lavik G, Schmid M and 5 others (2003) Anaerobic ammonium oxidation by anammox bacteria in the Black Sea. Nature 422:608-611

Larsen LH, Kjær T, Revsbech NP (1997) A microscale NO3biosensor for environmental applications. Analyt Chem 69:3527-3531

Laughlin RJ, Stevens RJ (2003) Changes in composition of nitrogen-15-labeled gases during storage in septumcapped vials. Soil Sci Soc Am J 67:540-543

Li YH, Gregory S (1974) Diffusions of ions in sea water and in deep-sea sediments. Geochim Cosmochim Acta 38: 703-714

Lorenzen CJ (1967) Determination of chlorophyll and pheopigments - spectrophotometric equations. Limnol Oceanogr 12:343-346

Loy A, Horn M, Wagner M (2003) probeBase-an online resource for rRNA-targeted oligonucleotide probes. Nucleic Acids Res 31:514-516

Luther GW, Sundby B, Lewis BL, Brendel PJ, Silverberg N (1997) Interactions of manganese with the nitrogen cycle: alternative pathways to dinitrogen. Geochim Cosmochim Acta 61:4043-4052

Meyer RL, Kjær T, Revsbech NP (2001) Use of $\mathrm{NO}_{\mathrm{x}}^{-}$microsensors to estimate the activity of sediment nitrification and NOx- consumption along an estuarine salinity, nitrate, and light gradient. Aquat Microb Ecol 26:181-193

Mulder A, van de Graaf AA, Robinson LA, Kuenen JG (1995) Anaerobic ammonium oxidation in a denitrifying fluidized bed reactor. FEMS Microbiol Ecol 16:177-184

Nielsen K, Nielsen LP, Rasmussen P (1995) Esturine nitrogen retention independently estimated by the denitrification rate and mass balance methods: a study of Norsminde Fjord, Denmark. Mar Ecol Prog Ser 119:275-283

Nielsen K, Risgaard-Petersen N, Somod B, Rysgaard S, Bergo $\mathrm{T}$ (2001) Nitrogen and phosphorus retention estimated independently by flux measurements and dynamic modelling in the estuary, Randers Fjord, Denmark. Mar Ecol Prog Ser 219:25-40

Nielsen LP (1992) Denitrification in sediments determined from nitrogen isotope pairing. FEMS Microbiol Ecol 86: $357-362$

Editorial responsibility: Bess Ward,

Princeton, NJ, USA
Newell RIE, Cornwell JC, Owens MS (2002) Influence of simulated bivalve biodeposition and microphytobenthos on sediment nitrogen dynamics: a laboratory study. Limnol Oceanogr 47:1367-1379

Payne JW (1981) Denitrification. John Wiley \& Sons, New York

Pelegri SP, Nielsen LP, Blackburn TH (1994) Denitrification in estuarine sediment stimulated by irrigation activity of the amphipod Corophium volutator. Mar Ecol Prog Ser 105:285-290

Revsbech NP (1989) An oxygen microelectrode with a guard cathode. Limnol Oceanogr 34:474-478

Risgaard-Petersen N, Rysgaard S (1995) Nitrate reduction in sediments and waterlogged soils measured by ${ }^{15} \mathrm{~N}$ techniques. In: Alef K, Nannipieri P (eds) Methods in applied soil microbiology. Academic Press, New York, p 287-296

Risgaard-Petersen N, Nielsen LP, Rysgaard S, Dalsgaard T, Meyer RL (2003) Application of the isotope pairing technique in sediments where anammox and denitrification coexist. Limnol Oceanogr: Methods 1:63-73

Rysgaard S, Fossing H, Jensen MM (2001) Organic matter degradation through oxygen respiration, denitrification, and manganese, iron, and sulfate reduction in marine sediments (the Kattegat and the Skagerrak). Ophelia 55:77-91

Schmid M, Twachtmann U, Klein M, Strous and 5 others (2000) Molecular evidence for genus level diversity of bacteria capable of catalyzing anaerobic ammonium oxidation. Syst Appl Microbiol 23:93-106

Schmid M, Walsh K, Webb R, Rijpstra WIC and 11 others (2003) Candidatus 'Scalindua brodae', sp. nov., candidatus 'Scalindua wagneri', sp. nov., two new species of anaerobic ammonium oxidizing bacteria. Syst Appl Microbiol 26: $529-538$

Stief P, De Beer D, Neumann D (2002) Small-scale distribution of interstitial nitrite in freshwater sediment microcosms: the role of nitrate and oxygen availability, and sediment permeability. Microb Ecol 43:367-378

Strous M, Fuerst JA, Kramer EHM, Logemann S and 5 others (1999) Missing lithotroph identified as new planctomycete. Nature 400:446-449

Svensson JM, Enrich-Prast A, Leonardson L (2001) Nitrification and denitrification in a eutrophic lake sediment bioturbated by oligochaetes. Aquat Microb Ecol 23:177-186

Thamdrup B, Dalsgaard T (2000) The fate of ammonium in anoxic manganese oxide-rich marine sediment. Geochim Cosmochim Acta 64:4157-4164

Thamdrup B, Dalsgaard T (2002) Production of N-2 through anaerobic ammonium oxidation coupled to nitrate reduction in marine sediments. Appl Environ Microbiol 68: 1312-1318

Trimmer M, Nicholls JC, Deflandre B (2003) Anaerobic ammonium oxidation measured in sediments along the Thames Estuary, United Kingdom. Appl Environ Microbiol 69:6447-6454

Zumft WG (1992) The denitrifying prokaryotes. In: Barlows A (ed) The prokaryotes: a handbook on the biology of bacteria: ecophysiology, isolation, identification, applications. Springer-Verlag, Berlin, p 554-582

Submitted: December 18, 2003; Accepted: April 2, 2004

Proofs received from author(s): July 5, 2004 